\title{
ECOLOGICAL SECURITY AND MILITARY ORGANIZATION IN THE DIGITAL AGE
}

\author{
Zoran Mačak and Milan Kankaraš \\ Ministry of Defence of Republic of Serbia, \\ Strategic Planning Department \\ Dejan R. Đorđević
}

Serbian Armed Forces, Military Geographical Institute

\begin{abstract}
reoccupation of the public with ecological problems escalated during the last decades of the $20^{\text {th }}$ century, and it has incredibly increased during this century, as well. Ecological security is a certain contemporary phenomenon that is present in diverse organizational units. This field is full of uncertainty and risks. From the moment of realizing that ignorance of ecological threats violates personal and collective security to a considerable extent and causes long-term and often catastrophic consequences to the environment, the need for ecological enlightenment has been recognized in many modern systems. The military organizations, which are the most complex security structures, are not an exception.

This paper deals with security ecological risks in the military organizational systems and it emphasizes possibilities for effective action through constructive use of achievements of the modern digital age.
\end{abstract}

Key Words: ecological security, military organizations, IT use

\section{Introduction}

Ecological threats in the contemporary world are getting more and more clear and direct. Due to digitization and improved availability of information, the awareness of their presence and consequences, which their negligence can have to the overall security, has overcome the level of expert and scientific circles. Nowadays, more than ever, one should strive for harmony with nature. Despite intensive research, ecological threats cannot be still used to precisely define spatial boundaries and conclude definitely when local threats become state ones, state threats become regional ones, regional threats become continental ones, and continental threats take a global level. Neither an individual nor the society, economic and non-governmental organizations, state and non-state actors is spared ecological security threats.

This work is based on the following premises: firstly, ecological security in the modern age is becoming rather important part of the overall security; secondly, there are close ties of activities of the military organizational systems with challenges, risks and threats in the field of ecology; thirdly, in the contemporary military organizational systems the work on effective and efficient conduct of ecological security can be significantly enhanced by using 
achievements of the modern digital age. Thus structured, the paper is divided into three parts. The first one is focused on contemporary aspects of ecological security, the second one deals with concentrization of the subject area to the specific (military) organization, and the third one highlights the possibility of the use of digitization in the elaborated field.

\section{Ecological security}

\section{Transformation of approach to security}

The term "security", despite hardly measurable number of expert and scientific papers dealing with it that originate from the ancient times (the beginning of literacy), has always represented the term with various meanings. It has usually been connected to the military sphere, and after the Westphalian Treaty (1648) it became the field of interest of the state.

In the broadest sense, security means safety and a kind of freedom from fear, threats and physical violence. Security is reflected as safety, as well, that is the lack of danger and it represents one of the most fundamental needs. The well-known American psychologist and philosopher Abraham Maslow places safety of each person - individual immediately after physiological needs in his original approach to hierarchy of human needs (Maslow, 2014). Furthermore, Hobbes regards peace and security as the highest individual and social values (Stojanović, 2012). Certain definitions explain it as the state (protection of some property, current value, society), organization (protection mechanism in various organizational forms) and function (attribute of the state despite the character of its organization, political system and form of government) (Vojni leksikon, 1981), as well as "the state of the activity where there is no manifestation of danger" (Терлецкая, 2011). Security is a universal goal for everyone, yet hardly attainable. The total civilization development is marked by security deficit. The theorist Joseph Nye regards security as "oxygen, which is simply accepted as the existing fact until the moment you start to miss it, and you cannot think of anything else" (Nye, 2003).

The important transformation of approach to security started at the end of the eighties of the last century. Military threats stop to be the central threats to the state security and besides the state, new subjects and objects of security emerge in the foreground, which makes the state lose its central primacy. Thus, the term security has widened (horizontal level) and deepened (vertical level). It has expanded from military to non-military fields human rights, climatic changes, political and economic stability, and it has also deepened the focus has moved from the state to an individual, the society, region, international system and global society (Ejdus, 2012). Therefore, the language of security is no longer restricted to the military sphere. Theorists have recognized and offered, and the public has accepted the so-called sector approach. Thus, sector represents a way to unpack the confusion of the whole by breaking it into several parts, which are analytically separated according to some special aspect. In that light, the theorists of the famous Copenhagen School make difference between military, ecological, economic, social and political sector (Buzan, Weaver and de Wilde, 1998). ${ }^{1}$ Slight variation is expressed by some authors a

\footnotetext{
${ }^{1}$ This division does not surprise because Barry Buzan in his early papers when dealing with national security regards the national security system as "the set of activities, which comprises five areas of the state operation: military, political, economic, social and ecological sphere" (Buzan, 1991).
} 
decade or two after that, where sectors are divided into military security, regime security, social security, ecological security and economic security (Collins, 2010).

Ecological threats as non-military threats, whose significance in the contemporary world is on the constant increase, have an important place in the newly established approach.

\section{Ecology and/or environment}

As with definition of many contemporary phenomena, terminological and semantic confusion surrounds the definition of ecology, as well (Table 1).

Table 1 - Definitions of ecology in dictionaries and lexicons (prepared by authors)

\begin{tabular}{|l|l|}
\hline \multicolumn{1}{|c|}{ Dictionary } & \multicolumn{1}{c|}{ Main meaning } \\
\hline Macmillan & $\begin{array}{l}\text { The relationship between the plants, animals, and the environment in a } \\
\text { particular area. }\end{array}$ \\
\hline Oxford & $\begin{array}{l}\text { The branch of biology dealing with mutual relations of organisms and their } \\
\text { physical surroundings. }\end{array}$ \\
\hline Cambridge & $\begin{array}{l}\text { The relationship between the air, land, water, animals, plants, etc., usually } \\
\text { of a particular area, or the scientific study of this. }\end{array}$ \\
\hline Longman & $\begin{array}{l}\text { The way in which plants, animals, and people are related to each other and } \\
\text { to their environment, or the scientific study of this. }\end{array}$ \\
\hline $\begin{array}{l}\text { American Heritage } \\
\text { Dictionary }\end{array}$ & $\begin{array}{l}\text { The science of the relationships between organisms and their } \\
\text { environments. }\end{array}$ \\
\hline $\begin{array}{l}\text { Dictionary of } \\
\text { Environment and } \\
\text { Ecology }\end{array}$ & $\begin{array}{l}\text { The study of the relationships between organisms, as well as their } \\
\text { relationships with the physical surroundings. }\end{array}$ \\
\hline Political lexicon & $\begin{array}{l}\text { The study of the relationships between living beings and nature and } \\
\text { environment they work and live in. }\end{array}$ \\
\hline
\end{tabular}

Despite the differences in understanding ecology, it has been noticed that ecology is the science (scientific discipline), whose area of interest are complex relationships of the broadest spectrum of living and non-living actors in the observed environment.

The approach of theorists is consistent with the attitudes expressed in dictionaries. Thus, Ernst Haeckel, who is considered to be its creator according to many people, defined ecology in 1866 as "the overall science about the relationships between organisms and the environment" (Aleksić and other authors, 2014). Ecology "studies the interaction between organisms mutually and between organisms and their environment with effects that organisms have on the non-living surroundings" (Lawrence 2003); "it studies the relationships between organisms, as well as the relationship with their physical surroundings" (Collin, 2004) and it represents "the science about living conditions, the relationships between living organisms mutually and non-organic part of the environment, the influence of a man on nature and consequences of their activities" (Терлецкая 2011). The complexity of action field points at the existence of many problems. 
The wider public identifies ecological problems as problems of the environment. Applying the identical approach (dictionary search) the environment is "the place in which people live and work, including all the physical conditions that affect them; the conditions and influences in which people carry on a particular activity; the natural world, including the land, water, air, plants, and animals, especially considered as something that is affected by human activity (Macmillan); „the environment or conditions in which people, animals, and plants live or work; the natural world, as a whole or in certain geographical area, especially affected by man's activities" (Oxford); the air, water, and land that people, animals, and plants live in; the conditions that you live or work in and the way that they influence how you feel or how effectively you can work" (Cambridge); the air, water, and land on Earth, which is affected by man's activities (Longman) and "the totality of the natural world" (American Heritage Dictionary).

On the basis of the comparative analysis with the comprehension of ecology, the main difference that is noticed is related to man's activities. In this context, the following picture can be both connected to ecology (totality and connection of surroundings) and the environment (noticeable influences of a man).

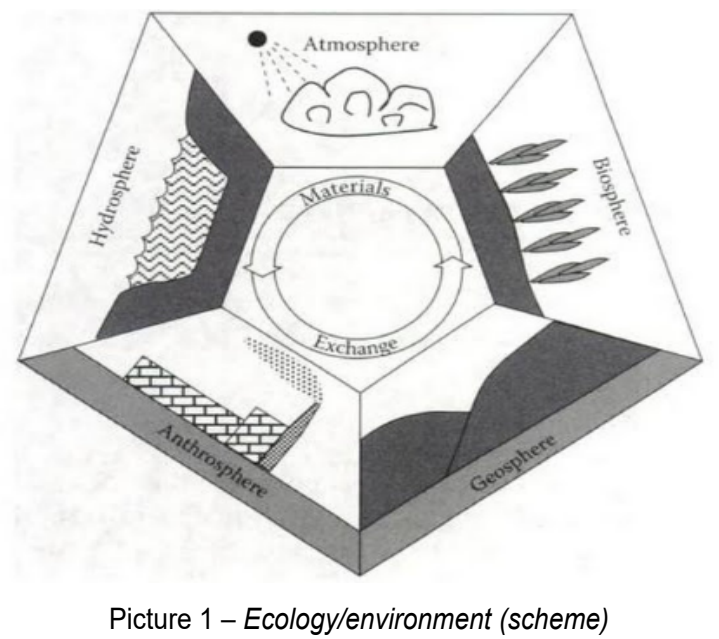

(Todd, N. J. (2005): A Safe and Sustainable World: The Promise Of Ecological Design. Washington, D.C.: Island Press, p. 36)

Theorists express different views. Some of them insist that ecology as the science should be separated from the protection of the environment and nature, which are the applied parts of ecology; that there should be difference between communal hygiene and ecology and ecologists (Bachelor of Ecology, Bachelor of Ecological Engineering, etc. versus the environment fan) (Aleksić, 2014). The other theorists think that the terms environment and ecology can be equally used and they do not insist on difference. To ecologically study living beings does not mean to research only them as a special natural species, but to address the problem comprehensively with wider habitat and all conditions of life and development that these beings are involved with (Bajagić, 2012). 
Ecology has been undoubtedly established after the environment. However, it is surely in focus because it emerged when economic human activity (uncontrolled consumption of natural resources) visibly started to degrade the environment and questioned not only human survival ${ }^{2}$. Destructive activities of nature have not stopped by the occurrence of ecology. Precise chroniclers have recorded that from 1979 until 2004 there were more than 230 natural disasters. However, beginning from a gas leak incident in the Indian city Bhopal in 1984, they recorded until 2004 nearly 100 catastrophes caused by a man (Collin, 2004). A consumer of this information probably does not think whether this is "the ecological problem" or "the environmental problem". Ecology is getting more omnipresent. Nowadays, a few human activities can ignore ecology. Ecology becomes an unavoidable part to everyone who analyses the environment that is the totality of mutually connected external and internal factors. ${ }^{3}$

Not questioning the need for as clear as possible semantics and precise conceptual categorical apparatus, one should bear in mind the similarity of the term expression in different languages. In this context, terms represent the form, but the essence is more important. Despite terminological traps, the basics of man's action nowadays should be protection from the physical surroundings response to their activities that is how to be and remain safe to themselves and the environment in such surroundings.

\section{Ecological security as a type of security}

The study of ecological security is a recent phenomenon. "The Resolution on international ecological security" adopted by the UN General Assembly in 1987 in response to the Chernobyl disaster is considered to be a reference written document. ${ }^{4}$ From scientific point of view, the accepted manner of ecology and security symbiosis represents sector approach to security. The reference object in ecological sector is the environment. Within approach to the term security, the explanation of ecological security is included. Thus, ecological security is the state of security of each individual, the society, state and nature from excessive danger to the environment, that is preservation and protection of vital interests of an individual and the environment from negative anthropogenic and natural effects, thus being the significant component of the state security (Черняховский, 2007); that is the state of protection of ecosystems from chemical and nuclear catastrophes, industrial pollution, land or water degradation, local and planet ecological changes (Ejdus, 2010); "the system of scientific, technical, social, organizational and other measures that guarantee mutually harmonic existence and development of nature and man and the state of protection of an individual, the society and state from the effects of an-

\footnotetext{
${ }^{2}$ There is a large number of endangered species (over 80 ) that are alphabetically arranged from the Amsterdam albatross to yellow ash frog (more in Collin, 2004).

${ }^{3}$ There are many techniques of analyzing how the environment influences phenomena and processes. Ecological influence is a constituent of one of more famous and highly positioned managerial techniques PESTLE analysis.

${ }^{4}$ The important report "Our common future" by the World Commission on Environment and Development (WCED) was published the same year. The report warns, inter alia, there is a danger that ecological degradation and resource scarcity will lead to instability and conflicts (Ejdus, 2012).
} 
thropogenic influence to the environment, as well as natural disasters and catastrophes (Russian World Encyclopedia)"; ${ }^{5}$ then, the combination of actions and processes like development of new technologies that do not lead to damage to nature, individual and humankind as a whole (Терлецкая, 2011).

For some theorists from the group of those who advocate clear distinction between the terms ecology and environment, ecological security should enable sustainable development whereas the environmental security should be connected to removing threats to political stability caused by ecological problems (Rogers, 1997).

In response to ecological problems, national and international legislation take an active part, international conventions are adopted, inspections are conducted, agencies are established, standards are made, ${ }^{6}$ media, citizens, and organizations are included. The interest in ecological problems is illustrated by the fact that during the $20^{\text {th }}$ century over 900 multilateral treaties in the field of environmental protection were signed, and they represent the area of interest of over 28.000 ecological non-governmental organizations in the world (Bajagić, 2012).

Security faces various risks. In ecological milieu a risk represents certain level of probability that some activity will directly or indirectly cause a danger to the environment, life and health of people and break the optimal relationship in the natural surroundings. Ecological security should enable risk minimization without selective approach. Not only wealthy individuals, societies and states should be ecologically secure, although the history is full of opposite examples. ${ }^{7}$

Sector approach demands that ecological security should be regarded as the content of integral security. Taking this into account, ecological security has to be the joint venture of many, especially state actors. The military organization as the system, where security is de facto and de jure the basic field of work (occupation), is not an exception.

\section{Military organization as ecological security actor}

Organization is a civilization creation made from the need to achieve by collective work what cannot be done by individual work. According to one of many classifications, an organization can be profit and non-profit one. In such context, the military organization is non-profit organization in which the employees by collective work achieve socially justified goals connected to the state security and society as a whole.

Nowadays in defense structures, especially in the ministries responsible for defense and the Armed Forces, there are significant reasons for interest in ecological security. There is a growing need to properly understand ecological challenges, risks and threats both within their organizations and broader social surroundings. Having this in mind, special interest should be related to those segments where the military structures have more expressive interests, that is ecological problems of local governments, the problem

\footnotetext{
${ }^{5}$ http://politike.ru/termin/ekologicheskaja-bezopasnost.html

${ }^{6}$ ISO 14000 is a family of over 25 standards. The methodology that it is based on is "Plan-Execute-CheckAct". The Eco-Management and Audit Scheme (EMAS) EU program regulated by the European Council Directive No. 761/2001 is also well-known.

${ }^{7}$ In the so-called "countries in transition" high levels of industrial pollution and practice of inadequate disposal of various (sometimes imported), even nuclear waste have been recorded (Petrović, 2012).
} 
of the existing technical-technological resources and the field of arms and military equipment production, that is defense industry ${ }^{8}$ they rely on.

In the context of source of ecological threats not even the Armed Forces are immune to natural disasters. They are vulnerable to floods, earthquakes, fires, avalanche, hurricanes, acid rains, rock fall, landslide, extreme temperatures, the lack of drinking water, etc. (Novaković and Mačak, 2015) like all other social structures. Thereby, their role is often more emphasized then because besides "self-assistance" they are required to render assistance to "civil structures". Despite the fact that the Armed Forces have to include such scenarios in their plans in the mentioned field, greater engagement should be expressed in the sphere of potential catastrophes, which are the result of human activities, and the most important engagement should be focused on ecological risks of their own activities.

It is the fact that goals of the military activities are often not in accordance with goals of ecology. Peace in ecological sphere is hardly attainable without armed conflicts. While preparing for them accommodation facilities should be built, obstacle courses and training grounds should be put into use, arms and military equipment should be produced, stored and transported, etc. The necessity of rather complex and multipurpose military installations often poses risks of ecological degradation for broader social community (more in Lawrence and other authors, 2015). There are numerous production companies in service of the military organizations. From ecological point of view, the environmental pollutants are mainly representatives of the industry that uses chemical-technological, engineering processes for production of arms and military equipment. In the majority of countries these are factories for production of ammunition and explosive ordnance, and in some countries these are factories that produce nuclear, biological or chemical weapons. Ecological risk from pollution in production plants can be present during technological process, disposal of production process remains (waste) $)^{9}$ and risks in case of hazardous events (Milinović and other authors, 2008).

The Armed Forces are not the greatest environmental pollutant at peace. However, they are often the greatest pollutant in armed conflicts they prepare for. A war deserves special consideration. Although it has overcome its original meaning, a war in the discourse of armed conflicts still represents the most destructive form of armed conflict, where often something and someone who is not an adversary is killed. ${ }^{10}$ The very physiognomy of war

\footnotetext{
8 "The defense industry" is not immanent to all countries. The term itself is debatable because a large number of countries produce arms and military equipment for attacks, often thousand kilometers away from their borders. In this context, especially from ecological point of view, the explanation that they "defend their interests" on the foreign ground is unconvincing.

${ }^{9}$ Waste can have 5 different states of aggregation (gaseous, solid, amorphous solid, liquid and mixed). Its dangerous effect is usually neutralized by the use of aggressive substances and chemical compounds, although larger quantities of neutralized waste have harmful effect on the environment (Milinović and other authors, 2008). Dangerous waste is not often treated in compliance with regulations, which results in its accumulation, and improper management due to restricted storing and warehousing capacities.

${ }^{10}$ Waging the chemical war in which Americans used 64 million liters of chemical substances in South Vietnam resulted in the destruction of 2 million hectares of forests, and the land expelled from 26 million craters caused by bombing amounts to 3.5 billion cubic, which is 50 times more than the quantity of the land and sand dug out in the Panama and Suez Canal together (Specijalni rat, 1974). In Vietnam the experiments with the so-called "firestorms" were conducted, as well, large fires were generated, over 50.000 rain bombs were used; in the Gulf War the military bomber aircraft set around 700 oil plants on fire for 8 months, and during NATO intervention in FRY munitions with depleted uranium were used (Klem and other authors, 2017). The news that during 78 days of bombing in FRY the ecosystem was threatened, chemical plants, oil refineries and storages bombed is disturbing, but rather general. What disturbs
} 
adapts to changes. Therefore, the military theorists are acquainted with the term "ecological warfare". One of the most comprehensive sources of scientific and expert data related to the military action in the Balkans (from the period of SFRY) - the Military lexicon defines "ecological warfare" as the destruction and pollution of nature and environment of people (water, air, plants and animals) in order to create unfavorable conditions for life and fight of the Armed Forces and population of an adversary. This type of warfare uses different chemical, biological and other ordnance (chemical agents, herbicide, flammable substances, explosive devices with time effect, the so-called meteorological weapons, etc.). It has also been applied in local wars, and in nuclear war ecological warfare would spread with catastrophic consequences (Vojni leksikon, 1981). It can be easily concluded that although the abovementioned definition was created four decades ago, that is before the Copenhagen School and sector approach to security, it preserves the feature of applicability in the modern age. There are papers on the need to consider the newly established field of applied ecology called war ecology that was created in order to understand the relationship between war and ecology (Machlis and Hanson, 2008), although those relationships are sometimes difficult to understand (Picture 1). Gloomy forecasts envisage that biosphere will probably continue to suffer for humankind, which is constantly preoccupied with war (Lawrence and other authors, 2015). War can never be made easy, humane and clean!

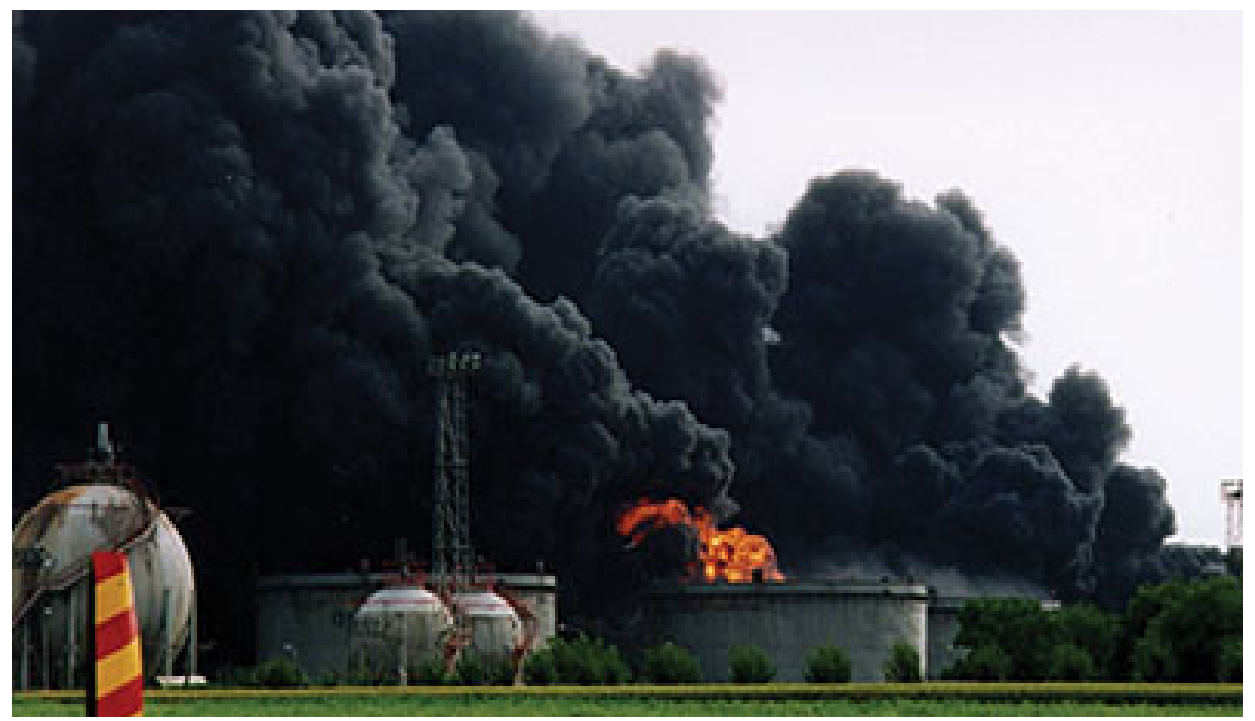

Picture 2 - Bombing of oil refinery in Novi Sad

(Klem, E., Bakrač, T. S. and Milanović M. (2017): Ecological Consequences of Warfare, Vojno delo 4/2017, Beograd, Media Centre „Odbrana”, p. 132)

more are the less known black rains (unburned particulates of oily substances from daily fires), the change in behavior of pets and some species of animals in Belgrade Zoo (including cannibalism and self-mutilation), abandoning natural habitats by some species of birds, mass killing of fish, honey with toxic substances, etc. (Pavlović, 2012). 
Due to growing awareness of the security aspects of environmental problems, defense structures had to react. Since 1993, when the job vacancy of the Deputy Secretary of Defense in charge for ecological security was formed in the US Department of Defense (Ejdus, 2012), the majority of the militaries have included ecological topics in strategic and doctrinal documents and documents at lower hierarchical levels. As if solving the dilemma: in the short term have (victory, fame, loot) or in the long term be (survive), the contemporary military organizations advocate at least declaratively the use of ecological ethics and the famous " 3 R" principles of ethics - Respect, Responsibility, Results towards the environment. At first glance the following principles seem to be related to an organization that deals with ecology, and not the military organization: ${ }^{11}$

- to encourage sustainability as lifestyle;

- to proactively take into consideration ecological consequences of all activities;

- to create and support economic and ecologically sustainable solutions;

- to continue to bear corporate responsibility;

- to think about surroundings and systemic approach to risk management during life cycles of projects and programs;

- to use scientific, economic and social knowledge for comprehension of the context of environment; and

- to use an open and transparent process, which respects attitudes of individuals and groups that are interested in our activities.

The military organizations have been more often enemies than friends to the environment. They still have the unfavorable effect on the state of the environment by their engagement in peacetime, and especially their engagement in the state of emergency, immediate war danger and a war itself. Measures, procedures and activities that can be used to remove, minimize or at least reduce such unfavorable effect require seriousness of approach at all decision-making levels. The technique of the modern age should not necessarily have unfavorable features, but on the contrary, it can be a chance for improvement.

\section{Advanced Technology and Digitalization as a Chance for Improvement of Ecological Security of the Military Organizations}

The use of innovation and the most modern products has always been characteristic of the militaries and battles or, as Toffler would emphasize, since the ancient times when the weak Israelite David defeated the Philistine Goliath with the help of the highly technological weapons at that time - catapult (Toffler, 1998). However, until the Industrial Revolution, the military activities did not largely damage nature. The military technologies of the Industrial Age introduced innovations, often ecologically destructive, such as chemical agents, destructive explosives, missile armament, nuclear and hydrogen bombs. ${ }^{12}$

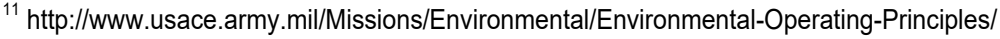

12 The other products of previous technologies used by the militaries have also caused serious degradation of nature and significantly decreased its regenerative power. A can falls apart for 100-500 years, plastic nonbiodegradable bag for a million years, and a glass bottle never.
} 
Nowadays we have the age of knowledge, which becomes "the central resource of productivity" (Toffler, 1998). The military is a pioneer in production and use in many fields that are a constituent of the digital discourse today. The first computer, Internet, communication devices, audio-visual devices and various software solutions have been made in the military or for the military purpose. Nowadays the military uses the modern age of electronics for tangible (hardware) and intangible (software) solutions, which seem to ignorant people like something not reachable or too futuristic. When it comes to software, it is hard to define the limits of its development. The power of digitization is illustrated by the following example related to software: not long ago (in the nighties of the last century) a car was $90 \%$ made from hardware and $10 \%$ from software whereas today such relation is $50 \% / 50 \%$, and very soon it will be $10 \% / 90 \%$. Undoubtedly, in the modern militaries this is applicable to the field of modernization of transport and fighting vehicles (autonomous movement of towing vehicles, planes, ship, tanks, etc.), mobile platforms, communication and crypto protective devices, surveillance equipment (radar, optoelectronic devices), etc.

The increase in energetic efficiency contributes to ecological security. Not questioning the significance of energy from fossil fuels (often fatal for ecosystem) so far, solar and geothermal energy, energy from biomass (related to treatment of organic waste), wind energy and energy from other sources (energy of tide, heat energy of sea and energy of sea waves (Stević and other authors, 2010) are used for the military purpose. Having this in mind, using contemporary technological achievements not only contributes to construction of new facilities, but to adaptation and reconstruction of the existing facilities of the military infrastructure, barracks, obstacle courses and training grounds, as well.

The industry in the service of the military today should be comprised of modern production based on research and development and completely sensitive to environmental requirements. Although the necessary resources for subsequent reactions (when ecological incidents have already happened) are made, production should be focused on prevention. Thus, "dirty technologies" and harmful substances such as lead and asbestos become the past, and plasma and nanotechnologies, new composite materials and "smart alloys" the future (Stević and other authors, 2010). Electromagnetic rail guns also announce the decreased use of gunpowder, satellite and GIS have rendered a long time ago assistance to the military formations not to get into the fog or sandstorm, thermo vision makes monitoring easier ${ }^{13}$, a robot places sensor where a man does not dare - contaminated atmosphere or factory chimney, audio barriers eliminate noise around military airports, tank, artillery and missile plants, 3D models and 3D printers save resources and decrease length of production processes, etc.

Natural environment is no longer the only place where the military activities are practiced, not only of an individual, but many units, as well. Owing to virtual reality and artificial intelligence, the land, water and air are much less needed during training, and thus less vulnerable. Simulators (Picture 3 ) describe reality more faithfully and exclude the need to make paper targets (trees are not cut in order to get cellulose), they prevent explosion from setting the environment on fire and causing stress of animals, they decrease the use of kerosene ${ }^{14}$ and do not disturb underwater peace. Miniaturization of cameras on drone or helmet of a soldier enables recording the real military activities (e.g. real tank battles), and then faithful simulation and practice of future crew.

\footnotetext{
${ }^{13}$ It is successfully used in prevention of coal self-ignition in warehouses.

${ }^{14}$ It is considered that the military planes use $2 / 3$ of ecologically harmful kerosene.
} 


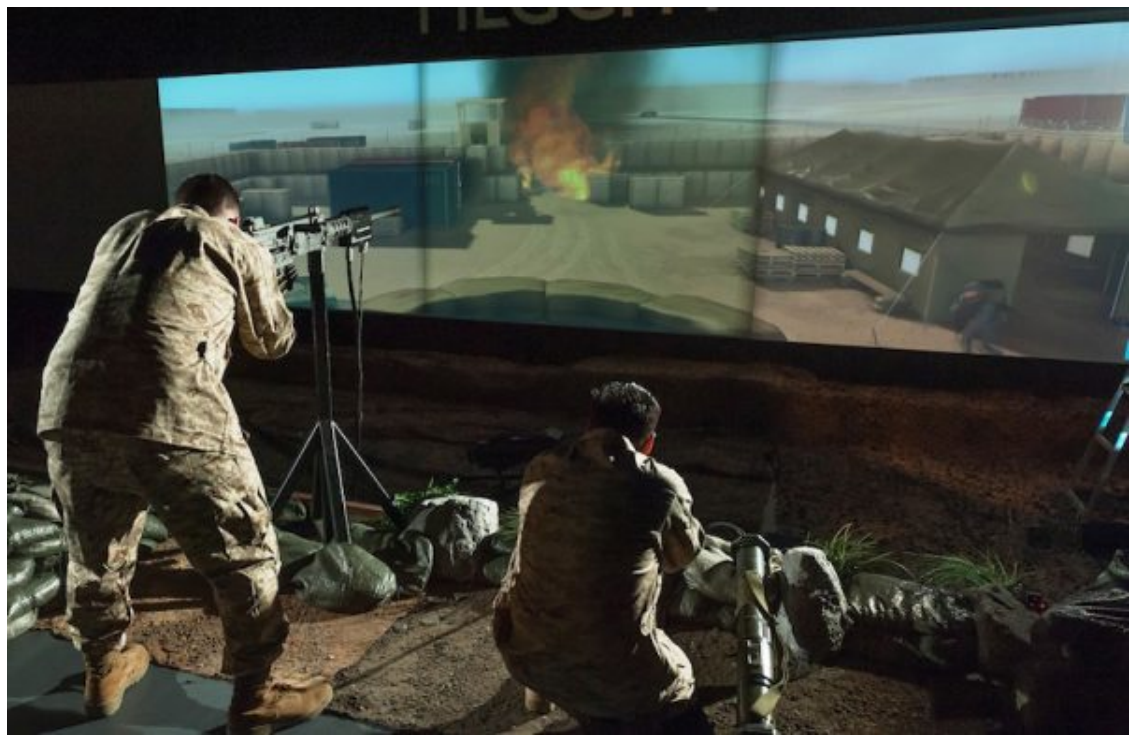

Picture 3 - Use of simulations in military training

(http://sas-egypt.net/Simulations/advanced-weapons-simulator-sas-aws/)

IT has changed the role of commander. Digitalized display of the battlefield and its surroundings in real time shortens the response time of a decision-maker and at the same time it decreases the risk of harmful consequences to actors of battle and the environment. The decision-making supporting tools ${ }^{15}$ as a rather modern product related to expansion of IT make the work of decision-makers much easier.

Modern technology has enabled the principle of "continuity" that is constant alertness in monitoring to be absolutely present. Relevant data manipulation has been constantly speeded up. Various records of ecologic indicators (European Environment Agency, 2014), which contain data for ecological environment assessment that is ecological risk assessment can be more easily recorded and edited, archived and saved, analyzed and searched, put in a desired layout, selected and adapted to a user.

Due to universal representation, the other military organizations are not spared "the ecological battles". The study and adaptation of foreign experiences, which are assessed as useful, can help enhance the existing own measures, activities and procedures. Nowadays there are neither strategic and doctrinal documents (the National Security Strategy, the Defense Strategy, the White Paper on Defense) nor annual reports on work that do not include the field of ecological security in their content. The IT advantages have made it possible that it is no longer a rarity to select very quickly on the official websites of the Armed Forces information on planning, organizing, managing and evaluating, finance and normative and legal regulation of the field of ecological security.

\footnotetext{
${ }^{15}$ Thus, some militaries use the commercial software called @RISK, which is the addition to the program for table calculation Microsoft Office Excel (Mačak and other authors, 2017). According to the 2016 data, 64 universities and 214 large corporations in the world buy the abovementioned software.
} 
Rather digitalized media that most militaries possess today are also involved in spreading "green news" and promoting "examples of good practice", even if it means the use of adequate dustbins for waste selection in the military camps.

From ecological point of view, the goals of the contemporary military organization should be: more intensive and efficient training, more responsible use of resources, introduction of healthier technologies, reduction in emission of harmful substances and waste recycling, adoption of ecological standards and active participation in the initiatives for protection of the environment and education of employees when it comes to protection of the environment. Reaching the stated goals will make the military organization important support to ecological security. Digitization will make the way to their achievement easier.

\section{Conclusion}

Security has a long time ago stopped to have only the state and military meaning. One of its meaning which must not be ignored in the modern world is related to ecological sphere. Today ecological risks greatly differ from the ones in the past. Undoubtedly, humankind is in the millennium of escalation of ecological problems. The forms of environmental threats get new, mainly unfavorable features. Unfortunately, the bright face of industrialization and technological boom has its back rather expressed in the field of ecology. Devastation, desertion and destruction of the environment have been multiplied by the use of sophisticated weapons and military equipment by the military organizations. The military activities will continue to cause ecological degradation in the future period and one should not be misled by the illusion that those activities will ever become harmless to the environment. However, there is more pronounced need for the modern militaries to work more intensely on minimization of damage in the environment. Today, more than ever, the militaries should strive to harmony with nature. The $21^{\text {st }}$ century military planners are forced to look into the future in greater details than their previous predecessors including a lot more aspects. The issues of ecological security are unavoidable. Proper understanding and use of digitization achievements in this exhausting and constant work through ecologically acceptable solutions will bring multiple benefits to both the military organization and the environment.

\section{References}

[1] Aleksić, J. i drugi (2014): Primenjena ekologija, vodič, Beograd: Plus kopi.

[2] Bajagić, M. (2012): Međunarodna bezbednost, Beograd: JP Službeni glasnik.

[3] Buzan, B. (1991): People, States and Fear, Harvester, New York, p. 14.

[4] Buzan, B., Weaver, O. \& de Wilde, J. (1998): Security: A New Framewor for Analysis, London: Lynne Rienner Publisher.

[5] Collins, A. (2010): Savremene bezbednosne studije. (R. Jakešević \& M. Suknaić, Trans.) Zagreb: Politička kultura.

[6] Collin, P. (2004). Dictionary of Environment and Ecology: Over 9,000 terms clearly defined, London: Bloomsbury Publishing,

[7] Черняховский, Э. Р. (2007): Управление экологической безопасностью, Москва: Альфа Пресc.

[8] Ejdus, F. (2012): Međunarodna bezbednost: teorije, sektori i nivoi, Beograd: JP Službeni glasnik i Beogradski centar za bezbednosnu politiku. 
[9] European Environment Agency (2014): Digest of EEA indicators, ISBN 978-92-9213-459-4

[10] https://ahdictionary.com/word/search.html

[11] http://dictionary.cambridge.org/dictionary/english/risk

[12] https://en.oxforddictionaries.com/definition/risk

[13] http://politike.ru/termin/ekologicheskaja-bezopasnost.html

[14] http://www.Idoceonline.com/dictionary/risk

[15] http://www.macmillandictionary.com/dictionary/british/

[16] http://www.usace.army.mil/Missions/Environmental/Environmental-Operating-Principles/

[17] Klem, E., Bakrač, T. S. and Milanović M. (2017): Ecological Consequences of Warfare, Vojno delo 4/2017, Beograd, medija centar „Odbrana”.

[18] Lawrence B. S.(2003): A Citizen's Guide to Ecology, Oxvord university press.

[19] Lawrence, J. M., Holly, L. J. S., Zolderdo J. A., Struther, P. D. and Cook, J. S. (2015): The effects of modern war and military activities on biodiversity and the environment, Environmental Reviews, 2015, 23(4), p. 443-460.

[20] Machlis, E.G. and Hanson T. (2008): Warfare ecology, BioScinence, Vol 58, No.8. American Institute of Biological Sciences.

[21] Mačak, Z., Babić, B., Isailović, M. (2017): Primena alata @RISK u prevenciji požara, Međunarodna nauĉno struĉna konferencija „Bezbednost i krizni menadžment, teorija i praksa,Obrenovac-Beograd: Donat graf, ISBN- 978-86-80698-08-3.

[22] Maslov, A. (2004): Psihologija u menadžmentu,Novi Sad, Adizes

[23] Milinović, M., Lukić, M., Jeremić, O. (2008): Ekološki rizici odbrambne industrije Republike Srbije, Beograd: Centar za monitoring i evaluaciju

[24] Novaković, S., Mačak, Z. (2015): Voda, bogatstvo koje nestaje, Međunarodna naučnostručna konferencija - Kako do kvalitetnijeg života, Zbornik radova, ISBN 978-86-84531-25-6

[25] Nye J. S. Jr., 2003, Understanding International Conflicts, Fourth edition, (Foreward by Stenley Hoffman), New York: Longman.

[26] Pavlović V. (2012): Ekologija i rat - Izveštaj nezavisnih eksperata o NATO bombardovanju $S R J$, Beograd: Službeni glasnik.

[27] Petrović, N. (2012): Ekološki menadžment, Beograd, Fakultet organizacionih nauka.

[28] Politički leksikon, (1979), Beograd: Udruženje publicista.

[29] Specijalni rat - psihološko propagandni aspekt, br 6-7, (1974), Beograd: SSNO - Centar za studije $\mathrm{i}$ istraživanja.

[30] Stević, Z., Nikolovski, D., Nikolić, Z., Kragić, R., Šamšalović, S., Kovačević, D. (2010): Tehnika i tehnologija u funkciji zaštite životne sredine, Beograd: SMEITS.

[31] Stojanović, S., (2012), Hobsova teorija ljudske prirode i perspektive mira i poretka, Beograd, Medija centar Odbrana

[32] Терлецкая, А. Т. (2011):Экология и безопасность жизнедеятельности, Хабаровск, ТОГУ.

[33] Toffler, A. (1998). Rat $i$ antirat, Beograd: Paidela.

[34] Todd, N. J. (2005). A Safe and Sustainable World: The Promise Of Ecological Design. Washington, D.C.: Island Press.

[35] Vojni leksikon, (1981), Beograd, Vojno-izdavački Zavod. 